\title{
Effect of Roasting Conditions on the Browning Index and Appearance Properties of Pulp Pre-Conditioned and Fermented Cocoa (Theobroma Cacao) Beans
}

\author{
Emmanuel Ohene Afoakwa ${ }^{1 *}$, Agnes Simpson Budu ${ }^{1}$, Henry Mensah-Brown², Jemmy Felix \\ Takrama $^{3}$ and Eric Ofosu-Ansah ${ }^{1}$ \\ ${ }^{1}$ Department of Nutrition \& Food Science, University of Ghana, Ghana \\ ${ }^{2}$ Department of Food Process Engineering, University of Ghana, Ghana \\ ${ }^{3}$ Cocoa Research Institute of Ghana, Ghana
}

Received: November 22, 2013; Accepted: January 20, 2014; Published: February 06, 2014

*Corresponding author: Emmanuel Ohene Afoakwa, Department of Nutrition \& Food Science, University of Ghana, P. O. Box LG 134, LegonAccra, Ghana, Tel: +233 (0) 244685893 / +233 203505 696; E-mail: eoafoakwa@gmail.com; eafoakwa@ug.edu.gh

\begin{abstract}
Appearance is an important quality determinant of cocoa beans and it is used as standard criteria to establish the degree of fermentation and drying of the beans. Changes in browning index and colour $\left(\mathrm{L}^{*} \mathrm{a}^{*} \mathrm{~b}^{*}\right)$ during roasting of pulp pre-conditioned and fermented cocoa beans were studied using standard analytical methods. Increasing pod storage and roasting time at $120^{\circ} \mathrm{C}$ led to variable increases in browning index (BI) and $b^{*}$-values of the beans with decreases in the $\mathrm{L}^{*}$ and $\mathrm{a}^{*}$ values. Cocoa pod stored for 10 days showed the highest BI (1.144) with the least $L^{*}$ value (24.15) whilst beans from the unstored pods showed the least BI (1.007) with the highest $\mathrm{L}^{*}$ value $(25.55)$. The rates of change in $\mathrm{BI}$ and colour $\left(\mathrm{L}^{*}\right.$, $\left.a^{*}, b^{*}\right)$ were however more pronounced during roasting than pod storage. Brown pigment formation (BI) and the $\mathrm{L}^{*}$ value were more pronounced after 30 minutes of roasting in beans from pods stored for 3 to 7 days. The colour changes in beans from 10 days pod storage was significant $(\mathrm{p}<0.05)$ after 45 minutes of roasting. The beans from the pods stored for 3 to 7 days showed consistent decrease in $\mathrm{L}^{*}$ and $\mathrm{a}^{*}$ values with increasing roasting time whiles the beans from the 10 days of pod storage were observed to produce lower $\mathrm{L}^{*}$ value (darker beans) after 45 minutes of roasting. Pod storage between 3 to 7 days could be used to improve the brownness and appearance of roasted cocoa nibs. Beans from cocoa pod stored between 3 to 7 days produced the most acceptable $\mathrm{BI}$ and $\mathrm{L}^{*}$ value after roasting for 30 minutes at $120^{\circ} \mathrm{C}$.
\end{abstract}

Keywords: Cocoa beans; Pulp pre-conditioning; Pod storage; Roasting; Browning index; Colour

\section{Introduction}

Roasting is critical to the flavour and appearance qualities of cocoa beans during industrial processing. The choice of roasting conditions depend on the variety and quality of cocoa, the cultivation conditions and primary processing after harvesting [1]. The roasting conditions determine the character of the chemical and physical processes that occur inside the beans, as well as the quality of the final products [1]. During roasting, several physical and chemical changes occur in the cocoa beans such as evaporation of volatile acids, causing reduction in the acidity hence reducing the sourness as well as bitterness of the cocoa beans. These changes lead to the production of desirable chocolate flavours and colour [2] by maillard reaction. The flavour precursors viz., free amino acids, short-chain peptides, and reducing sugars $[3,4]$ produced during fermentation interact during the roasting to produce the desirable flavour compounds such as pyrazine, alcohols, esters, aldehydes, ketones, furans, thiazoles, pyrones, acids, imines, amines, oxazoles, pyroles, and ethers [5-8]. The quality of the flavours produced is dependent on several factors, such as the origin of the beans, period of harvesting, postharvest treatment, variety and the roasting conditions [4,9-14].

Colour development occurs during roasting and is mediated by 3-deoxyxylose and 3, 4-dideoxyxylose-3-en during the roasting process [15]. These two substances and other reactive precursors participate in condensation and polymerization reactions that yield brown polymers containing carbonyl, carboxyl, amino, amide, indole, pyrrole, ester, ether, methyl and hydroxyl groups [15]. The nature of the end product of the Maillard reaction depends on the roasting time and temperature and on the $\mathrm{pH}$, reactant concentration and water activity of the roasting beans $[1,8]$. Temperature is reported to be the main factor affecting pigment formation during roasting of cocoa beans [16-18] to give the desirable brown colour of chocolate. As well, the dynamics of pigment formation upon roasting depends on temperature gradient [17]. Krysiak W [19] showed that roasting using convective oven at higher temperature $\left(135\right.$ and $\left.150^{\circ} \mathrm{C}\right)$ and higher humidity of air (5.0\%) displayed desired colouration (OD460/OD525 above 1.1 and F1/F3 below 0.33) for fermented and dried cocoa beans that were not pulp pre-conditioned.

Pulp pre-conditioning, fermentation and drying also have been reported to increase the brownness of cocoa beans [11]. During fermentation, polyphenols and anthocyanins undergo 
different reactions that lead to the synthesis of flobafens, which contribute to the characteristic brown colour of roasted beans. Also, polyphenols oxidation and polymerization, degradation of proteins, Maillard reactions and dextrinization of starch yield other brown pigments, similar to roasted cocoa [11,20-22].

Afoakwa et al. [23] indicated that pulp pre-conditioning by pod storage improve the fermentation outcome such as degree of brownness (fermentative index) in Ghanaian cocoa beans. Other researchers have also indicated that, pulp pre-conditioning improve the flavour outcome in cocoa beans during roasting. The roasting process increase brown pigment formation and affect the colour properties ( $L^{*}, a^{*}, b^{*}$ values) [11]. However, the extent to which pulp pre-conditioning by pod storage may affect the degree of brown pigments formation during roasting as well as appearance or colour qualities of the beans still remains unknown. This research was therefore aimed at evaluating the changes in browning index and appearance (colour) properties during roasting of pulp pre-conditioned and fermented cocoa beans.

\section{Materials and Methods}

\section{Raw materials}

Fully ripe mixed hybrid variety was obtained from the cocoa plantation of the Cocoa Research Institute of Ghana (CRIG), NewTafo in the Eastern Region of Ghana.

Sample preparation: Freshly and fully ripe good looking cocoa pods were harvested, sorted out to remove the bruise ones and divided into four parts, each containing three hundred (300) pods. The pods were stored in a heap form for four different storage times $(0,3,7$ and 10 days) on the bear concrete floor under shade and broken after the specified days of storage. The beans were scooped out and fermented for six days using the basket fermentation technique. The fermenting cocoa beans were opened and mixed after every 48 hours until the fermentation process was over. The fermented cocoa beans were sun dried with stirring four times each day to allow uniform drying of the beans.

Cocoa samples were randomly picked into black air tight bags at intervals and moisture content analysed until a moisture content ranged between 5.5 to $6 \%$ was attained. The cocoa beans were immediately packaged in air tight black plastic bags prior to roasting. Roasting was done according to the method described by Owusu $\mathrm{M}$ et al. [24] with slight modifications. The fermented and dried mixed hybrid cocoa beans packaged in air tight black plastic bags were sorted to remove all the smaller and flat beans. About $500 \mathrm{~g}$ of the beans was weighed and roasted using hot air oven in batches at a temperature of $120^{\circ} \mathrm{C}$ for $0,15,30$ and 45 minutes. For each of the roasting treatments under investigation, the oven temperature was set at $120^{\circ} \mathrm{C}$ and left to equilibrate for at least 30 minutes. The fermented dried cocoa beans (500 g) were spread in a single layer in the perforated metallic sample tray and then placed on the oven shelf close to the thermometer.

After roasting, the cocoa beans were transferred to another tray and allowed to cool to room temperature and placed in air tight black plastic bags according to the duration of pod storage and roasting. The samples were stored at ambient temperature $\left(25-28^{\circ} \mathrm{C}\right)$ in a dark room free from strong odours until used. The procedure was repeated for the different pulp pre-conditioned treatments. The cocoa beans were shelled manually using knife and milled using kitchen blender for further analyses.

Experimental design: A $4 \times 4$ full factorial design with the principal experimental factors as pod storage $(0,3,7$ and 10 days) and roasting time $(0,15,30$ and 45 minutes $)$ at $120^{\circ} \mathrm{C}$ were used to study the changes in the browning index and colour.

\section{Analytical methods}

Browning index $\left(\mathbf{O D}_{460} / \mathbf{O D}_{525}\right)$ : The browning index of the nibs was determined using [25] method with slight modifications. Approximately $0.1 \mathrm{~g}$ of the ground cocoa sample was weighed into a test tube and $10 \mathrm{ml}$ of methanol: $\mathrm{HCl}(97 \%: 3 \%, \mathrm{v} / \mathrm{v}$ ) was added and vortex for about 2 minutes. The sample mixture was kept in the cold room at a temperature of $6^{\circ} \mathrm{C}$ for 20 hours and cooled to room temperature. Aliquot of the top clear solution was taking into the curvette and absorbance taken at wavelengths of $460 \mathrm{~nm}$ and $525 \mathrm{~nm}$ using UV/Visible spectrophotometer (Beckman Coulter spectrophotometer, Duisburg, Germany). The browning index was calculated using the following formula $\left(\mathrm{OD}_{460} / \mathrm{OD}_{525}\right)$. The analysis was conducted in triplicates and the mean value reported.

Colour measurement: Hunter Lab $\operatorname{Miniscan}^{\mathrm{TM}}$ XE Colorimeter Model 45/0 LAV (Hunter Associates Inc., Reston, VA) calibrated with white ceramic reference standard was used to measure the colour of the cocoa nibs. Colour images of chocolate surfaces were converted into XYZ tristimulus values, which were further converted to CIELAB system: $\mathrm{L}^{*}$, luminance ranging from 0 (black) to 100 (white); and $a^{*}$ (green to red) and $b^{*}$ (blue to yellow) with values from -120 to +120 . The $L^{*}, a^{*}, b^{*}$ values were taken in triplicates and the mean values calculated and reported.

\section{Statistical analysis}

The data obtained was analyzed using Statgraphics (Graphics Software System, STCC, Inc. U.S.A). Analysis of variance (ANOVA) was used to determine the relationships between the studied attributes. Significance was established at a probability of $\mathrm{p}<0.05$. All treatments and measurements were conducted in triplicates and the mean values and standard deviations reported.

\section{Results and Discussion}

\section{Effect of pod storage and roasting time on the browning index $\left(\mathrm{OD}_{460} / \mathrm{OD}_{525}\right)$ of the cocoa nibs}

Roasting temperature is the main factor affecting colour development, flavour, and texture. These changes are mainly related to Maillard reactions during roasting. The Maillard reactions cause an increase in brown pigment formation, causing an increase in the $\left(\mathrm{OD}_{460} / \mathrm{OD}_{525}\right)$ values of roasted food samples. Evaluation of colour of roasted cocoa beans is one of the methods used to assess their quality.

The browning index of the dried fermented beans increased 
significantly $(\mathrm{p}<0.05)$ with increasing pod storage (Table 1$)$. It increased from 1.007 for the unstored pods to 1.007, 1.096 and 1.144 for 3,7 and 10 days pods storages respectively (Figure 1). The significant $(\mathrm{p}<0.05)$ increase in browning index $\left(\mathrm{OD}_{460} /\right.$ $\mathrm{OD}_{525}$ ) with increasing pod storage was in agreement with earlier findings in which fermentative index was to measure the degree of brown pigment formation in cocoa beans [26]. The increase in the browning index with increasing pod storage might be due to rapid degradation of the polyphenols into brown pigments (tannins) during fermentation [27].

Also, increasing roasting time of the cocoa beans for all pod storage treatments lead to significant $(\mathrm{p}<0.05)$ increases in the browning indices $\left(\mathrm{OD}_{460} / \mathrm{OD}_{525}\right)$ of the cocoa nibs. The browning index of the cocoa beans from the unstored pods increased significantly $(\mathrm{p}<0.05)$ from 1.007 prior to roasting to 1.414 after 45 minutes roasting. Similar trends of increase were observed for 3, 7 and 10 days pod stored beans. These findings are consistent with other finding by Krysiak W [25] and Bonvehi JS \& Coll VF [21]. The increase in browning index with increasing roasting time was probably due to increase in brown pigment formation from Maillard reactions, thermal oxidation and polymerization of polyphenols to form tannins [28] and Strecker degradation reactions $[22,25]$ during the roasting process. The interaction between pod storage and roasting time had a significant $(\mathrm{p}<0.05)$ influence on the browning index (Table 1).

Table 1: ANOVA summary table showing F-ratios for the changes in browning index and colour of pod stored and fermented cocoa beans during roasting.

\begin{tabular}{|l|l|l|l|l|}
\hline \multirow{2}{*}{ Variables } & Browning index & \multicolumn{3}{|c|}{ Colour measurements } \\
\cline { 4 - 6 } & $\left.\mathbf{( O D}_{460} / \mathbf{O D}_{525}\right)$ & $\mathbf{L}^{*}$-value & a*-value & $\mathbf{b}^{*}$-value \\
\hline Pod storage & $8.76^{*}$ & $51.55^{*}$ & $128.19^{*}$ & $62.13^{*}$ \\
\hline Roasting time & $223.45^{*}$ & $70.56^{*}$ & $217.44^{*}$ & $191.14^{*}$ \\
\hline Interaction & $4.82^{*}$ & $15.78^{*}$ & $7.93^{*}$ & $4.00^{*}$ \\
\hline
\end{tabular}

*Significant at $\mathrm{p}<0.05$

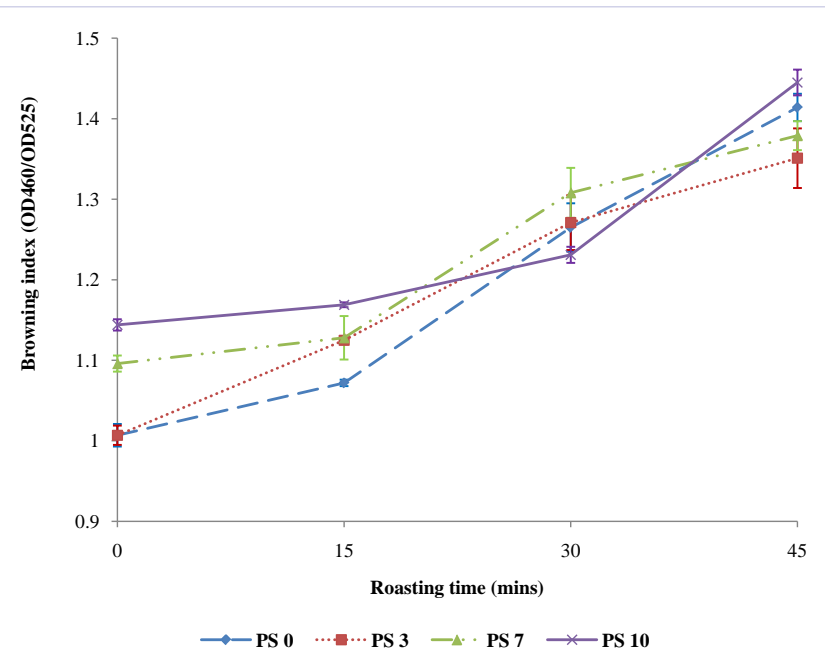

Figure 1: Effect of pod storage (PS) and roasting time on the browning index $\left(\mathrm{OD}_{460} / \mathrm{OD}_{525}\right)$ of cocoa nibs.

\section{Effect of pod storage and roasting time on colour measurements}

Colour is one of the indicators used to ascertain the quality of a fermentation process. Fermentative index, also known as browning index as well as visual appearance by cut tests are used to ascertain the appearance (colour) quality of fermented and dried cocoa beans.

Changes in $L^{*}$-values of the cocoa nib: The $L^{*}$ value indicate the degree of lightness of a sample. Increasing pod storage and roasting time decreased significantly $(p<0.05)$ the $L^{*}$ values of the cocoa nibs for all pod stored beans (Table 1). The fermented and dried cocoa beans from the unstored pods had $\mathrm{L}^{*}$ value of 25.55 and those from pods stored for 3,7 and 10 days had $L^{*}$ values of 25.57, 25.60 and 24.15 respectively. Cocoa beans for 10 days pods storage had the least $\mathrm{L}^{*}$ value (24.15), indicating a darker beans when compared to the beans from the unstored pods and pods stored for up to 7 days.

Variable trends in $\mathrm{L}^{*}$ values of the cocoa nibs were observed for increasing roasting time (Figure 2). The $\mathrm{L}^{*}$ value for the cocoa beans from the unstored pods decreased from 25.55 prior to roasting to 24.05 after 45 minutes roasting. Similar trends were observed for 3,7 and 10 days pods stored cocoa beans (Figure 2). However, the beans from the 10 days pod storage showed drastically reduced $L^{*}$ values below 20 suggesting that beans from 10 days of pod storage would produce darker beans after 45 minutes of roasting. These dark beans might affect the appearance of their derived products making them darker (not chocolate brown) and unacceptable. The significant decreases in the $\mathrm{L}^{*}$ values of the beans with increasing roasting time might be due to Maillard products formation. The interaction between pod storage and roasting time had a significant $(p<0.05)$ influence on the $\mathrm{L}^{*}$ values of the beans (Table 1 ). With the exception of the 10 days pod stored beans, the $\mathrm{L}^{*}$ values were all positive which indicated that, the beans were lighter even after roasting for 45 minutes.

Changes in $a^{*}$-values of the cocoa nibs: Figure 3 shows changes in $a^{*}$-values of the cocoa beans during pod storage and roasting. The $\mathrm{a}^{*}$ values of the fermented and dried cocoa beans decreased from 12.50 for the unstored pods to $12.33,10.75$ and 9.22 for 3,7 and 10 days pods stored beans respectively (Figure $3)$. The decrease in the $a^{*}$ values with pod storage might be due to leaching out of some of the polyphenols and anthocyanins from the beans during the pod storage period as suggested by Hii et al. [27].

Changes in $a^{*}$-values of the cocoa nibs during roasting for all pod storage treatments are shown in Figure 3. Increasing roasting time caused significant $(\mathrm{p}<0.05)$ decrease in $\mathrm{a}^{*}$-values of the cocoa nibs for all pod stored treated beans (Figure 3).

The $\mathrm{a}^{*}$ values for the unstored cocoa beans decreased from 12.50 prior to roasting to 8.43 after 45 minutes roasting. The observation made was contrary to that of Summa et al. [29]. The decrease in the $a^{*}$ values of the cocoa nibs with increasing roasting time was due to thermal oxidation of the anthocyanins 
in the cocoa beans. The findings corroborate with earlier reports [30]. The interaction between pod storage and roasting time had a significant $(\mathrm{p}<0.05)$ influence on $\mathrm{a}^{*}$ values of the cocoa beans (Table 1). The $\mathrm{a}^{*}$ values were all positive for the unroasted beans, which meant the cocoa beans from the different pod storage treatments had more of a red/ magenta colour. This might have been caused by the presence of some purple beans, which were less fermented than others. The a* values for the roasted cocoa beans were all positive after roasting, which meant not all the anthocyanins were degraded during the roasting process hence, the cocoa beans had more of a red colour after roasting.

Changes in $\mathbf{b}^{*}$-values of the cocoa nibs: Increasing pod storage increased significantly $(p<0.05)$ the $b^{*}$ values of the cocoa beans (Table 1). The beans for the unstored pods had $a b^{*}$ value of 6.91 which increased slightly to 6.94 for 3 days pod stored beans but increased significantly $(\mathrm{p}<0.05)$ to 8.55 and 8.65 for 7 and 10 days pod stored beans respectively. Variable trends were

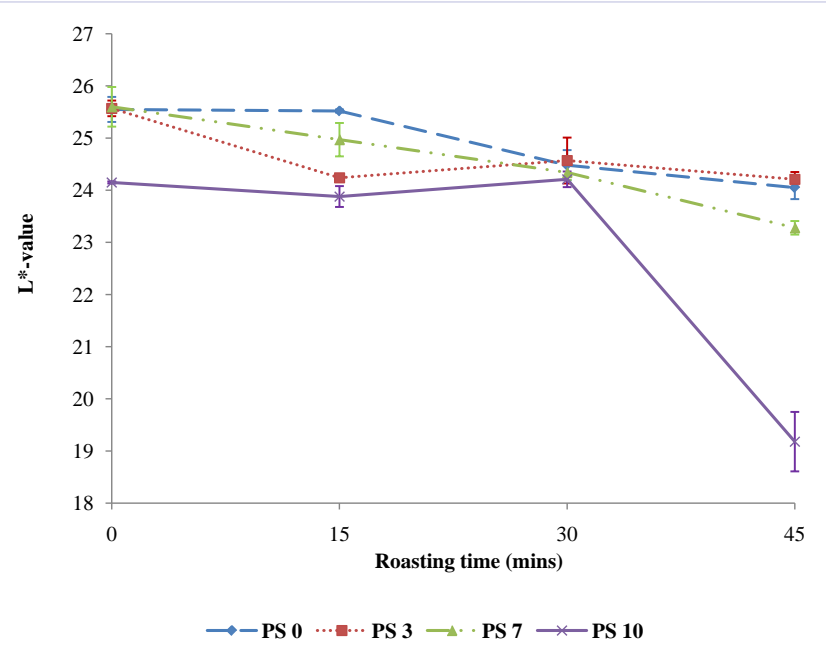

Figure 2: Effect of pod storage and roasting time on the $\mathrm{L}^{*}$-values of cocoa nib.

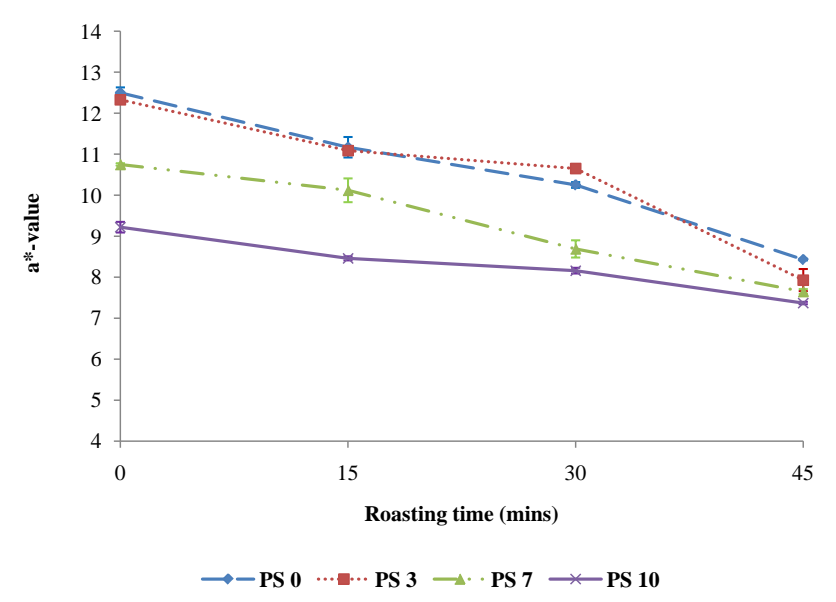

Figure 3: Effect of pod storage and roasting time on the a*-values of the cocoa nibs.

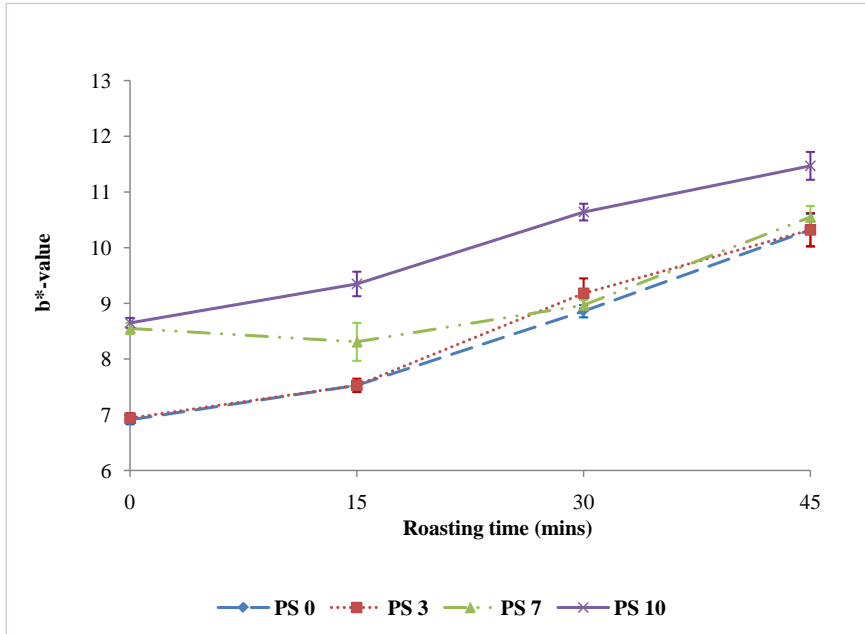

Figure 4: Effect of pod storage and roasting time on the $b^{*}$-values of cocoa nibs.

observed for increasing pod storage and roasting time (Figure 4). A rapid increase in $b^{*}$ values for 0,3 and 10 days pods stored cocoa beans were observed with increasing roasting time whiles 7 days pod stored cocoa beans had $b^{*}$ value that decreased from 8.55 prior to roasting to 8.31 after 15 minutes roasting and it increased to 10.55 after 45 minutes roasting (Figure 4).

Similar trend was observed by Summa et al. [29]. The significant increases in $b^{*}$ values with increasing roasting time might be due to thermal oxidation of polyphenols as well as Maillard products formation. The interaction between pod storage and roasting time had significant $(\mathrm{p}<0.05)$ influence on the $b^{*}$ values of the pod stored beans (Table 1 ). However, the $b^{*}$ values for all pod stored beans before and after roasting were all positive which meant the cocoa beans were more yellowish (desirable) in colour than blue which is an undesirable colour of cocoa beans. The increasing positive $\mathrm{b}^{*}$ values with increasing pod storage period suggest that the process of pod storage could be used to enhance the appearance of fermented cocoa beans.

\section{Conclusion}

Increasing pod storage and roasting time caused variable trends in the browning index (BI) and colour properties of the fermented cocoa beans. The beans from the 10 days pod storage produced the highest browning index (1.144) whilst those from the unstored pods showed the least BI (1.007). The $\mathrm{L}^{*}$ and $\mathrm{a}^{*}$ values decreased with increasing pod storage, with the highest decrease attained after 10 days pod storage. Increasing roasting time caused the BI to increase significantly in all the pod stored beans. Similarly, the $b^{*}$ values increased consistently with increasing roasting time for all the pod stored beans. The $\mathrm{L}^{*}$ and $a^{*}$ values decreased variably with increasing roasting time. The beans from the pods stored for 3 to 7 days showed consistent decrease in $\mathrm{L}^{*}$ and $\mathrm{a}^{*}$ values with increasing roasting time whiles the beans from the 10 days of pod storage were observed to produce lower $\mathrm{L}^{*}$ value (darker beans) after 45 minutes of roasting. Pod storage between 3 to 7 days could be used to improve the brownness and appearance of roasted cocoa nibs. 
Beans from cocoa pod stored between 3 to 7 days produced the most acceptable $\mathrm{BI}$ and $\mathrm{L}^{*}$ value after roasting for 30 minutes at $120^{\circ} \mathrm{C}$

\section{Acknowledgment}

The authors are thankful to the Cocoa Research Institute of Ghana, Tafo, Eastern Region, Ghana for providing the cocoa pods samples and technical support.

\section{References}

1. Krysiak W, Motyl-Patelska L (2006) Effects of air parameters on changes in temperature inside roasted cocoa beans. Acta Agrophysica $7(1): 113-127$.

2. Afoakwa EO, Paterson A, Fowler M, Ryan A (2008) Flavour Formation and Character in Cocoa and Chocolate: A Critical Review. Crit Rev Food Sci Nutr 48(9): 840-857.

3. Counet C, Callemien D, Ouwerx C, Collin S (2002) Use of Gas Chromatography-Olfactometry to Identify Key Odorant Compounds in Dark Chocolate. Comparison of Samples before and after Conching. J Agric Food Chem 50(8): 2385-2391.

4. Frauendorfer F, Schieberle P (2008) Changes in Key Aroma Compounds of Criollo Cocoa beans during Roasting. J Agric Food Chem 56(21): 10244-10251.

5. Hoskin JC, Dimick PS (1994) Chemistry of flavour development in chocolate. In Beckett ST (ed.) Industrial Chocolate Manufacture and Use. (2ndedn), Van Nostrand Reinhold, New York, USA.

6. Jinap S, Rosli IW, Russly AR, Nordin LM (1998) Effect of roasting time and temperature on volatile component profiles during nib roasting of cocoa beans (Theobroma cacao). J Sci Food Agric 77(4): 441-448.

7. Nazaruddin R, Hassan O, Said M, Samsudin W, Noraini I (2006) Influence of roasting conditions on volatile flavor of roasted Malaysian cocoa beans. Journal of Food Processing and Preservation 30(3): 280 298.

8. Noor -Soffalina SS, Jinap S, Nazamid S, Nazimah HAS (2009) Effect of polyphenol and $\mathrm{pH}$ on cocoa Maillard-related flavor precursors in a lipidic model system. International Journal of Food Science and Technology 44: 168-180.

9. Misnawi S, Jinap S, Jamilah B, Nazamid S (2004a) Sensory properties of cocoa liquor as affected by polyphenol concentration and duration of roasting. Food Quality and Preference 15(5): 403-409.

10. Misnawi S, Jinap B, Jamilah S, Nazamid S (2004b) Effect of polyphenol concentration on pyrazine formation during cocoa liquor roasting. Food Chemistry 85(1): 73-80.

11. Afoakwa EO (2010) Chocolate Science and Technology. WileyBlackwell Publishers, Oxford, UK, p. 3-22.

12. Afoakwa EO, Kongor JE, Takrama JF, Budu AS, Mensah-Brown H (2013a) Effects of Pulp Preconditioning on Total polyphenols, O-diphenols and Anthocyanin concentrations during Fermentation and Drying of Cocoa (Theobroma cacao) Beans. Journal of Food Science and Engineering 3: 235-245.

13. Afoakwa EO, Kongor JE, Takrama JF, Budu AS (2013b). Changes in Acidification, Sugars and Mineral Composition of Cocoa Pulp during Fermentation of Pulp Pre-conditioned Cocoa (Theobroma cacao) Beans. International Food Research Journal 20(3): 1215-1222.

14. Afoakwa EO, Kongor JE, Takrama JF, Budu AS (2013c) Changes in nib acidification and biochemical composition during fermentation of pulp pre-conditioned cocoa (Theobroma cacao) beans. International Food Research Journal 20(4): 1843-1853.

15. Martins SIFS, Jongen WMF, Van Boeckel MAJS (2001) A review of Maillard reaction in food and implications to kinetic modelling. Trends in Food Science and Technology 11(9-10): 364-373.

16. Özdemir M, Devres YO (2000) Analysis of colour development during roasting of hazelnuts using response surface methodology. Journal of Food Engineering 45(1): 17-24

17. Lee SY, Yoo SS, Lee MJ, Kwon IB, Pyun YR (2001) Optimization of nibs roasting in cocoa bean processing with Lotte-better taste and colour process. Food Science and Biotechnology 10: 286-293.

18. Demir AD, Celayeta JMF, Cronin K, Abodayeh K (2002) Modelling of kinetics of colour change in hazelnuts during air roasting. Journal of Food Engineering 55(4): 283-292.

19. Krysiak W (2011) Effects of convective and microwave roasting on the physicochemical properties of cocoa beans and cocoa butter extracted from this material. Grasasy aceites 62(4): 467-478.

20. Minifie BW (1989) Chocolate, cocoa and confectionary: Science and technology. Chapman and Hall, New York, USA.

21. Bonvehil JS, Coll VF (1997) Evaluation of bitterness and astringency of polyphenolic compounds in cocoa powder. Food Chemistry 60(3): 365-370.

22. Nebesny E, Rutkowski J (1998) Effect of roasting and secondary fermentation on cocoa bean enrichment. Polish Journal of Food and Nutrition Sciences 48(7): 437-446.

23. Afoakwa EO, Quao J, Budu AS, Takrama J, Saalia FK (2011) Effect of Pulp Pre-conditioning on Acidification, Proteolysis, Sugars and Free Fatty Acids Concentration during Fermentation of Cocoa (Theobroma cacao) Beans. International Journal of Food Science \& Nutrition 62(7): 755-764.

24. Owusu M, Petersen AM, Heimdal H (2013). Relationship of sensory and instrumental aroma measurements of dark chocolate as influenced by fermentation method, roasting and conching conditions. Journal of Food Science and Technology 50(5): 909-917.

25. Krysiak W (2006) Influence of roasting conditions on coloration of roasted cocoa beans. Journal of Food Engineering 77(3): 449-453.

26. Afoakwa EO, Quao J, Budu AS, Takrama J, Saalia FK (2012) Influence of pulp pre-conditioning and fermentation on fermentative quality and appearance of Ghanaian cocoa (Theobroma cacao) beans. International Food Research Journal 19(1): 127-133.

27. Hii CL, Law CL, Suzannah S, Misnawi S, Cloke M (2009) Polyphenols in cocoa (Theobroma cacao L.). Asian Journal of Food and AgricultureIndustries 2(4): 702-722.

28. Patras A, Brunton NP, O’Donnell C, Tiwari BK (2010) Effect of thermal processing on anthocyanin stability in foods; mechanisms and kinetics of degradation. Trends in Food Science \& Technology 21(1): 3-11.

29. Summa C, McCourt J, Cammerer B, Fiala A, Probst M, et al. (2008). Radical scavenging activity, anti-bacterial and mutagenic effects of cocoa bean Maillard Reaction products with degree of roasting. Molecular Nutrition and Food Research 52(3): 342-351.

30. Nicoli MC, Anese M, Manzocco L, Lerici CR (1997) Antioxidant properties of coffee brews in relation to the roasting degree. LWT Food Science and Technology 30(3): 292-297. 